Article

\title{
Control of Surface Properties of Hyaluronan/Chitosan Multilayered Coatings for Tumor Cell Capture
}

\author{
Giulia G. Lima $^{1} \mathbb{D}^{\text {, João B. }}$ M. Rocha Neto ${ }^{1} \mathbb{D}$, Hernandes Faustino de Carvalho ${ }^{2}$ and $_{\text {Marisa Masumi Beppu }}{ }^{1, *}$ \\ 1 School of Chemical Engineering, University of Campinas, Campinas, São Paulo 13083-852, Brazil; \\ giuliagrassalima@gmail.com (G.G.L.); jbmrneto@gmail.com (J.B.M.R.N.) \\ 2 Institute of Biology, University of Campinas, Campinas, São Paulo 13083-862, Brazil; hern@unicamp.br \\ * Correspondence: beppu@unicamp.br
}

Citation: Lima, G.G.; Rocha Neto, J.B.M.; Carvalho, H.F.d.; Beppu, M.M. Control of Surface Properties of Hyaluronan/Chitosan Multilayered Coatings for Tumor Cell Capture. Polysaccharides 2021, 2, 387-399. https://doi.org/10.3390/ polysaccharides 2020025

Academic Editor: Azizur Rahman

Received: 30 April 2021

Accepted: 25 May 2021

Published: 30 May 2021

Publisher's Note: MDPI stays neutral with regard to jurisdictional claims in published maps and institutional affiliations.

Copyright: (c) 2021 by the authors. Licensee MDPI, Basel, Switzerland. This article is an open access article distributed under the terms and conditions of the Creative Commons Attribution (CC BY) license (https:// creativecommons.org/licenses/by/ $4.0 /)$.
Abstract: Prostate cancer (PCa) is a slow-growing neoplasm that has, when diagnosed in its early stages, great chances of cure. During initial tumor development, current diagnostic methods fail to have the desired accuracy, thus, it is necessary to develop or improve current detection methods and prognostic markers for PCa. In this scenario, films composed of hyaluronic acid (HA) and chitosan (CHI) have demonstrated significant capture potential of prostate tumor cells (PC3 line), exploring $\mathrm{HA}$ as a CD44 receptor ligand and direct mediator in cell-film adhesion. Here, we present a strategy to control structural and cell adhesion properties of HA/CHI films based on film assembly conditions. Films were built via Layer-by-layer (LbL) deposition, where the $\mathrm{pH}$ conditions (3.0 and 5.0) and number of bilayers $(3.5,10.5$, and 20.5) were controlled. The characterization of these films was carried out using profilometry, ultraviolet-visible (UV-VIS), atomic force microscopy (AFM) and contact angle measurements. Multilayer HA/CHI films produced at $\mathrm{pH} 3.0$ gave optimum surface wettability and availability of free carboxyl groups. In turn, at pH 5.0, the coverings were thinner and presented a smoother surface. Films prepared with 3.5 bilayers showed greater tumor cell capture regardless of the $\mathrm{pH}$ condition, while films containing 10.5 and 20.5 bilayers presented a significant swelling process, which compromised their cell adhesion potential. This study shows that surface chemistry and morphology are critical factors for the development of biomaterials designed for several cell adhesion applications, such as rapid diagnostic, cell signaling, and biosensing mechanisms.

Keywords: layer-by-layer; adsorption; hyaluronic acid; cell adhesion; multilayer films

\section{Introduction}

Prostate cancer (PCa) is a slow-growing neoplasm that causes second highest mortality among men, though presenting good chances of cure when diagnosed in its early stages [1] Currently, the diagnosis is performed through prostate specific antigens (PSA) detection and rectal examination, which do not present the desired accuracy and thus result in many false negative results [2]. Therefore, in this context, the development and improvement of rapid detection methods and prognostic markers for prostate cancer are of great importance in order to contribute to more effective treatments [3].

Towards that end, previous studies have shown great potential for multilayer polymeric films composed of hyaluronic acid (HA) and chitosan (CHI) in the selective capture of tumor cells $[4,5]$. This interaction is driven by the high affinity of the hyaluronate, present in the HA molecule, with CD44 receptors. CD44 is an extracellular glycoprotein that is particularly upregulated in immune cells, such as B lymphocytes, macrophages, and tumor cells [6,7]. When bonded to HA, one of its main ligands [8], CD44 is responsible for a range of cellular processes, such as cell proliferation, migration, and adhesion [9]. Furthermore, current discussions point to a possible correlation between CD44 expression and tumor cell metastasis [10-12], which supports the potential use of HA-based devices as diagnostic tools. 
Hyaluronic acid and chitosan are natural polymers that offer a number of advantages for use in biomedical materials, such as biodegradability, biocompatibility, and low toxicity [13]. In this way, the risk of triggering immune responses when interacting with living organisms becomes very low. $\mathrm{CHI}$ is a polymer obtained from the deacetylation of chitin [14], which can be found in a wide variety of sources, such as insects [15-17], fungi [18], and crustaceans [19]. Chitosan can vary in terms of molecular weight, degree of deacetylation, and dispersity, which are key properties in determining the molecule's physicochemical characteristics and biological behavior [20]. Moreover, chitosan can be synthesized in a range of derivative types in order to enhance a particular property [21]. For instance, molecular weight and degree of deacetylation, which is determined by D-glucosamine and $N$-acetyl- $D$-glucosamine groups in the polymer backbone, are determinant factors on modulating $\mathrm{CHI}$ antibacterial activity [22]. This particular application of chitosan $\mathrm{CHI}$ has been extensively investigated due to the electrostatic interaction between the positive charges of the amine groups of $\mathrm{CHI}$ and the negative charges in bacterial membranes, thus disrupting bacterial cell walls [23,24]. Furthermore, the use of chitosan as a building block for polyelectrolytic-based materials extends $\mathrm{CHI}$ applications to a variety of biomedical purposes, such as the development of drug delivery systems [25,26], biomarkers [27,28], wound dressings [29], tissue engineering [30,31], and as both treatment and prevention of microbial infections [32-35]. In turn, HA is a copolymer that occurs naturally in the human body as one of the main components of the extracellular matrix, being found in larger amounts in the eyes, skin, and connective tissues [36-38]. As well as CHI, hyaluronic acid is widely explored in the medical field, with applications in joint disorder therapies [39,40], implants [41], regenerative medicine [42,43], and drug delivery [44].

Moreover, $\mathrm{HA}$ and $\mathrm{CHI}$ are polyelectrolytes that have ionizable functional groups, being classified as anionic (negative) and cationic (positive), respectively. Thus, by using oppositely charged polyelectrolytes, it is possible to build multilayer films via Layer-bylayer (LbL) deposition, in such a way that the cohesion between the layers is maintained by electrostatic forces. Films based on $\mathrm{HA}$ and $\mathrm{CHI}$ have been used in several applications, such as antimicrobial surfaces [45,46], cell adhesion [47], drug delivery [48], biosensing [5], wound dressings [29,49], gene delivery systems [50,51], and tissue engineering [52].

The Layer-by-layer assembly technique, developed by Iler in 1996, consists of alternating immersions of a substrate in solutions of opposite charges [53], so that the deposition of the coatings occurs by adsorption [54]. It is a self-assembly process with no restrictions regarding the type of geometry and substrate [55], which allows the incorporation of a multitude of materials to the multilayer.

In this process, there are several possible formation conditions that can directly interfere on the functionality of the multilayer films, since they can lead to different topography conditions and physicochemical properties of the coatings [56,57]. Such parameters include $\mathrm{pH}$, ionic strength, and concentration of the polyelectrolytic solutions [58-60] as well as the number of bilayers deposited on the substrate [61]. For instance, previous studies have shown that it is possible to obtain tunable topography [62], hydrophilicity [63], drug delivery parameters [64], and cell adhesion conditions [65] by adjustment of polymeric solutions in Layer-by-layer assembly.

Given this context, this project proposes investigating the influence of the $\mathrm{pH}$ of the polyelectrolytic solutions and the number of bilayers deposited on the morphology and composition of $\mathrm{HA}$ and $\mathrm{CHI}$ films via LbL. In addition, the selective capture potential of the coatings in regard to tumor cells of the PC 3 strain, as well as the quality (form factor) and kinetics of adhesion, were then explored.

\section{Materials and Methods}

\subsection{Materials}

Chitosan (CHI), hyaluronic acid sodium salt (HA, from Streptococcus equi sp.), Polyethylenimine (PEI), Alcian blue (AB), and Rose Bengal (RB) were purchased from Sigma-Aldrich, St. Louis, MO, USA. All polyelectrolytes were used without further purifi- 
cation. Sodium hydroxide $(\mathrm{NaOH})$, sodium chloride $(\mathrm{NaCl})$, and hydrochloric acid $(\mathrm{HCl})$ were purchased from Synth (São Paulo, Brazil). Glass slides were used as substrates and purchased from Kasvi (São José dos Pinhais, Brazil). HAM-F12K cell culture media and streptomycin/penicillin (S/P, 5000 U.I./mL) were purchased from Lonza (Basel, Switzerland). Fetal bovine serum (FBS) and Dulbecco's Phosphate Buffered Saline (DPBS), DAPI, and Phalloidin were purchased from Sigma-Aldrich (St. Louis, MO, USA). The PC3 tumor line was obtained from the American Type Culture Collection (ATCC, Manassas, VA, USA).

\subsection{Methods}

\subsubsection{Polyelectrolyte Solutions}

Chitosan, hyaluronic acid, and polyethyleneimine (PEI) solutions were prepared at a concentration of $1 \%(w / v)$ with an ionic strength of $0.1 \mathrm{M} \mathrm{NaCl}$. CHI solution was solubilized in a $0.1 \mathrm{M}$ glacial acetic acid (HAc) solution, while HA and PEI were solubilized in Milli-Q water. The solutions were stirred for $24 \mathrm{~h}$ in the presence of $\mathrm{NaCl}$. The solutions were then divided into two portions each and adjusted to $\mathrm{pH}$ levels of $3.00 \pm 0.05$ or $5.00 \pm 0.05$, respectively.

\subsubsection{Preparation of Substrates}

Glass slides $(24 \mathrm{~mm} \times 24 \mathrm{~mm})$ were cleaned by ultrasonication with an aqueous solution of commercial detergent and Milli-Q water for $10 \mathrm{~min}$ each, respectively. The substrates were then dried at room temperature. Subsequently, they were treated with $\mathrm{O}_{2}$ plasma at $100 \mathrm{mTorr}$ for $15 \mathrm{~min}$ (720 V DC, $25 \mathrm{~mA} \mathrm{DC}, 18 \mathrm{~W}$; Harrick Plasma Cleaner, PDC-32G) and covered with a PEI precoating [4].

\subsubsection{Film Assembly via Layer-by-Layer Deposition}

Multilayer films were assembled by alternating immersions of the PEI precoated glass slides in $\mathrm{HA}$ and $\mathrm{CHI}$ solutions for $10 \mathrm{~min}$ each, followed by three rinsing steps with ultrapure water ( $2 \mathrm{~min}, 1 \mathrm{~min}$, and $1 \mathrm{~min}$, respectively) between each polyelectrolyte immersion. The LbL procedure was repeated for 3.5, 10.5, and 20.5 cycles for all films, setting HA as the outermost layer.

\subsubsection{Cell Adhesion Assays}

Prostate tumor cells of the PC 3 strain were cultured in HAM F12 K medium containing $10 \%$ fetal bovine serum and $1 \%$ penicillin/streptomycin. The culture was kept in a humidified incubator at $37^{\circ} \mathrm{C}$ and $5 \% \mathrm{CO}_{2}$, with periodic changes of the culture medium.

To highlight the cells adhered to the culture flasks surface, $1 \mathrm{~mL}$ of $0.25 \%(v / v)$ trypsin was used. In this way, the cells in suspension could be counted using a Neubauer Chamber. Then, the HA/CHI films were placed in culture wells, pipetted with the suspension, and left for $1 \mathrm{~h}$ in an oven for the incubation step.

Finally, the wells were rinsed with a DPBS Flush buffer at $\mathrm{pH} 7.4$ in order to remove the nonadhered cells. Micrographs were acquired using the Axio Observer.Z1 Zeiss inverted confocal L510 microscope (Carl Zeiss AG, Oberkochen, Germany).

\subsubsection{Physicochemical Characterization}

Film thickness was determined with a Dektak 150 stylus profilometer (Veeco, Plainview, NY, USA) at a force of $1.0 \mathrm{mg}$ and scan speed of $17 \mu \mathrm{m} / \mathrm{s}$. Measurements were taken in quintuplicate. To evaluate the availability of carboxyl groups in HA, the films were stained with the polycationic dye Alcian Blue (AB), whose absorbance reading is performed at a wavelength of $617 \mathrm{~nm}$. The analysis was carried out using an ultravioletvisible (UV-VIS) spectrophotometer (Schimadzu, Model 1800). The hydrophilic character of the films was assessed through contact angle measurements, which were carried out in a goniometer Krüss Easy DropDSA-150 (Hamburg, Germany) in the static sessile drop mode. Measurements were taken in sextuplicate. Film topography data was obtained with atomic force microscopy (AFM) images, which were taken with a Park NX-10 Atomic Force 
Microscope (Suwon, South Korea) in tapping mode at room temperature and a humidity of approximately $5 \%$. The AFM images and roughness data were analyzed using Gwyddion open software.

\section{Results and Discussion}

\subsection{Film Characterization}

\subsubsection{Profilometry}

Film thickness was assessed through profilometry. The results presented in Figure 1 indicate that the increase in $\mathrm{pH}$ range led to thinner films. This result is a consequence of the charge density assumed by both $\mathrm{HA}$ and $\mathrm{CHI}$ in the studied $\mathrm{pH}$ range.

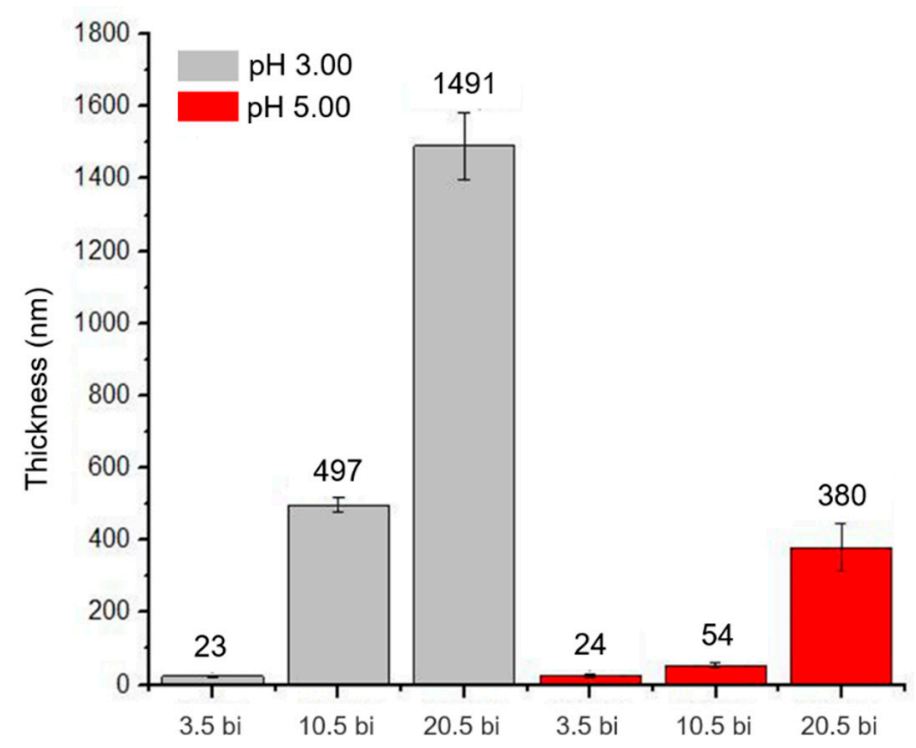

Figure 1. Average thickness of films prepared under different $\mathrm{pH}$ conditions and number of bilayers.

At both $\mathrm{pH} 3.0$ and $\mathrm{pH} 5.0$, chitosan $(\mathrm{pKa}=6.0)$ is highly charged, with about $99.90 \%$ and $90.91 \%$ of its functional groups ionized respectively. In turn, hyaluronic acid $(\mathrm{pKa}=2.9)$ is partially charged at $\mathrm{pH} 3.0$, with $55.73 \%$ ionized functional groups, while it is highly charged at $\mathrm{pH} 5.0$, where ionization levels reach $92.64 \%[37,66]$.

The charge density of the polymers in solution are determining factors for the conformation of their chains, in a way that the higher the charge density, the more linear the molecule is, due to the phenomenon of charge repulsion [67]. In this scenario, $\mathrm{CHI}$ adopts a stiff conformation regardless of the $\mathrm{pH}$ condition, while HA chains assume a random coil conformation at $\mathrm{pH} 3.0$ and a stiff conformation at $\mathrm{pH} 5.0$ [67]. Thus, the result of thicker films at $\mathrm{pH} 3.0$ is explained.

In addition, the coiled conformation of $\mathrm{HA}$ at $\mathrm{pH} 3.0$ provides a smaller surface area for approximation with other molecules, which means that a smaller portion of the negative charges of HA interact with the positive ones of $\mathrm{CHI}$. For this reason, a greater amount of HA molecules is required in order to compensate charges with CHI [66]. We suggest that a greater number of HA molecules is required in order to compensate charges with $\mathrm{CHI}$ for the film assembly [55]. Thus, there is a greater deposition of hyaluronic acid at $\mathrm{pH}$ 3.0, which contributes to an increase in the overall film thickness. Similar results were described by Montelongo et al. (2016) on the assessment of HA/CHI films under different $\mathrm{pH}$ conditions, where films assembled at $\mathrm{pH} 3.0$ presented the highest thickness measurements among the analyzed samples [46].

\subsubsection{UV-Vis}

The UV-Vis technique was employed to quantify the free carboxylic groups in the films using the Alcian Blue dye. The AB binds to the free carboxylic groups of hyaluronic 
acid, that is, those that do not participate in any interaction with the amino groups of chitosan [61]. Therefore, the higher the absorbance value, the more dye was incorporated by the film. $\mathrm{AB}$ absorbance measurements are shown in Figure 2 and are relative to both sides of the films.

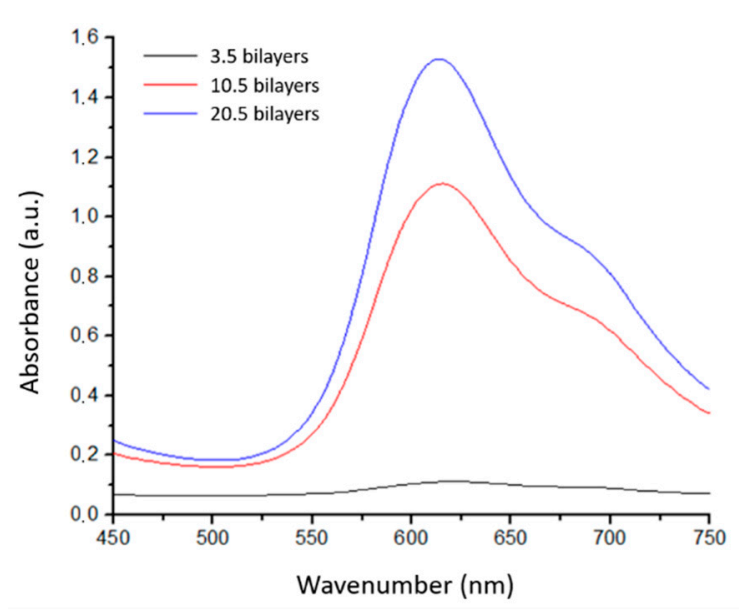

(a)

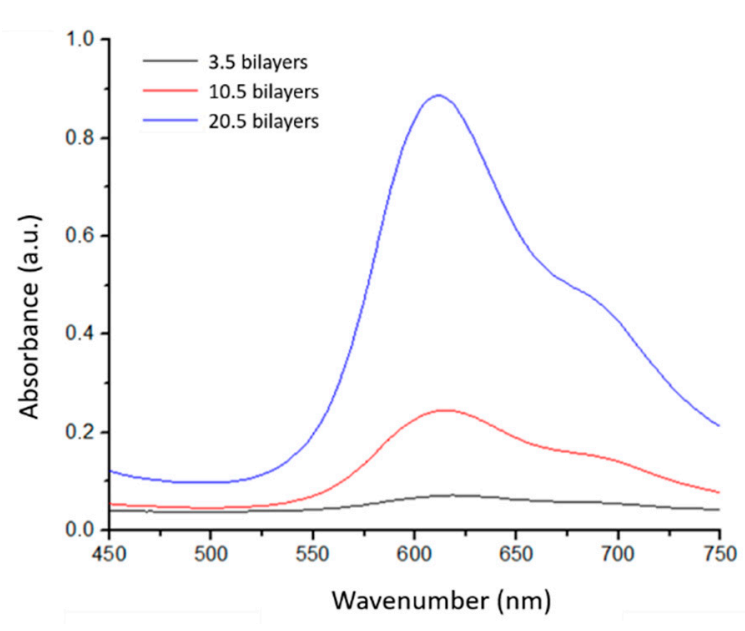

(b)

Figure 2. Absorbance of the films for 3.5, 10.5, and 20.5 bilayers under the conditions of (a) pH 3.0 and (b) pH 5.0.

It is observed that the increase in the number of bilayers, regardless of $\mathrm{pH}$, increases the absorbance of the dye in the films, which is expected since a greater number of deposited cycles promotes a greater adsorption of HA to multilayers. When comparing the films according to the $\mathrm{pH}$ conditions, the influence of charge density on the polyelectrolytes is again noted. At $\mathrm{pH}$ 3.0, the absorbance peaks are higher than at $\mathrm{pH}$ 5.0, which occurs for two reasons. The first is the higher concentration of hyaluronic acid in films prepared at $\mathrm{pH}$ 3.0, due to the need of more molecules to compensate charges with chitosan. The second is the fact that there is a greater number of free carboxylic groups to interact with the dye, since the coiled conformation of the HA chains creates a spatial impediment, allowing only a part of these groups to come into contact with the CHI molecules. In contrast, at $\mathrm{pH}$ 5.0, the carboxylic groups of HA are committed to the electrostatic interaction responsible for the formation of multilayers, since $\mathrm{CHI}$ is also highly charged and available. Nascimento et al. (2018) observed a similar AB incorporation trend regarding the number of bilayers and $\mathrm{pH}$ on $\mathrm{HA} / \mathrm{CHI}$ films [68].

\subsubsection{Contact Angle}

The hydrophilic character of the films was evaluated through contact angle measurements. With the aid of a goniometer coupled with software, values of the angles formed between drops of water and the surface of the coverings were obtained over time, as shown in Figure 3. The affinity for aqueous environments determines the permeation of the culture medium in the samples so that more hydrophilic surfaces provide a greater area of contact with the cellular environment. In this way, films with greater wettability tend to favor cell contact and subsequent adhesion [69]. 


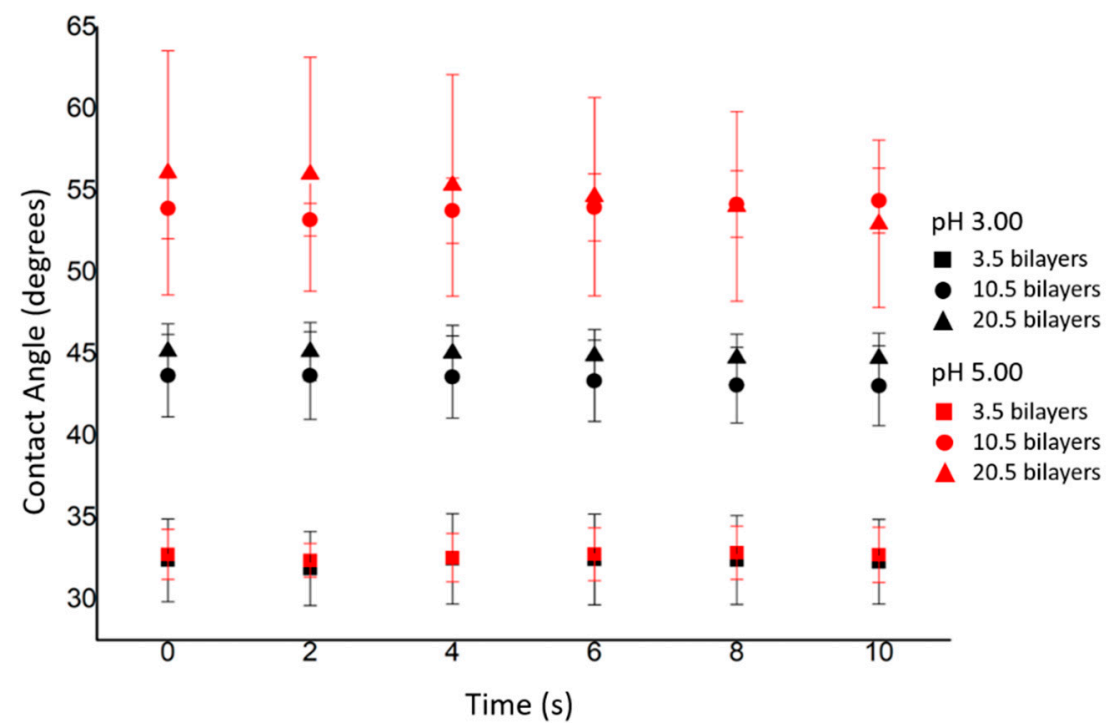

Figure 3. Measurement of contact angle over time for films built under different $\mathrm{pH}$ conditions and number of bilayers.

According to the results, there is no statistical difference in contact angle measurements over time, which shows that there is no considerable spread of the drop. Thus, it can be pointed out that the films offer good stability for the drop.

Moreover, a decrease in the contact angle was observed with the decrease of the $\mathrm{pH}$ condition from 5.0 to 3.0 for films assembled with 10.5 and 20.5 bilayers. As discussed before, due to the lower density of charges at $\mathrm{pH} 3.0$, there is a higher amount of HA chains in the films prepared in this condition. Hyaluronic acid is one of the most hydrophilic molecules found in nature [37], which corroborates to the greater surface wettability found in HA/CHI films assembled at $\mathrm{pH} 3,0$, since they contain a higher amount of HA.

Regarding the films assembled with 3.5 bilayers, no significant changes were observed in contact angle results with an increase in $\mathrm{pH}$ levels. The same effect was found for films with 10.5 and 20.5 bilayers within the same $\mathrm{pH}$ condition. Therefore, we suggest that up to 10.5 bilayers, the number of deposited layers is the leading factor for modulating the hydrophilic character of the coverings, whereas for films built with over 10.5 bilayers, the increase in $\mathrm{pH}$ levels then becomes the key factor for controlling this property.

\subsubsection{Atomic Force Microscopy (AFM)}

Through atomic force microscopy analysis, the mean square roughness of the nanometric films was determined, the values of which are shown in Table 1. Figure 4 shows the AFM images of the coatings.

Table 1. Roughness values of nanometric coatings for different $\mathrm{pH}$ conditions and number of bilayers.

\begin{tabular}{ccc}
\hline pH Condition & Number of Bilayers & Roughness (nm) \\
\hline \multirow{2}{*}{3.00} & 3.5 & $13 \pm 3$ \\
& 10.5 & $44 \pm 12$ \\
\multirow{2}{*}{5.00} & 20.5 & $42 \pm 6$ \\
& 3.5 & $8 \pm 1$ \\
& 10.5 & $23 \pm 4$ \\
& 20.5 & $21 \pm 6$ \\
\hline
\end{tabular}


(a)

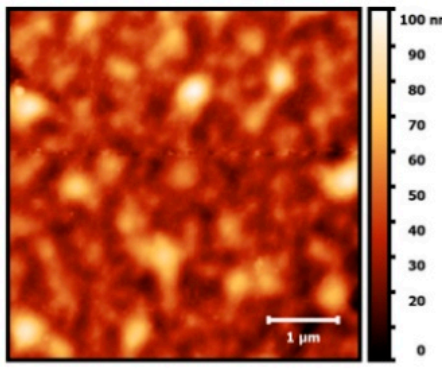

(d)

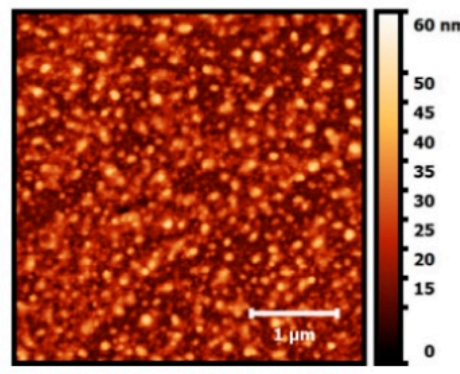

(b)

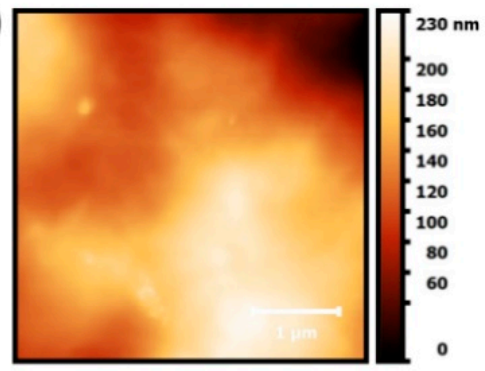

(e)

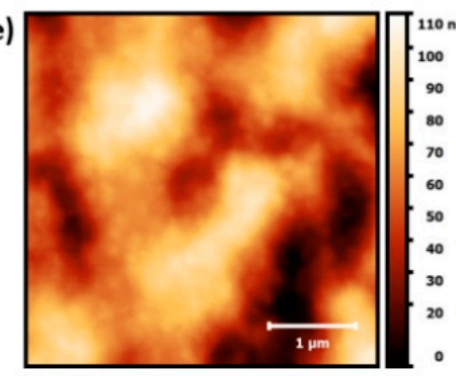

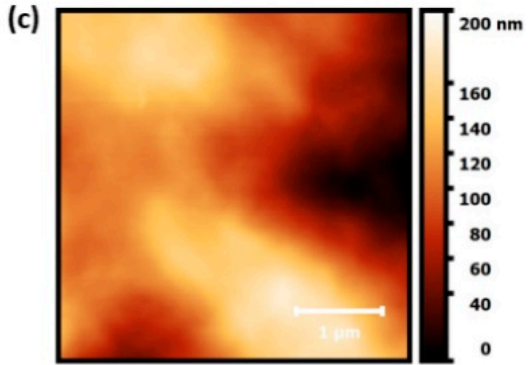

(f)

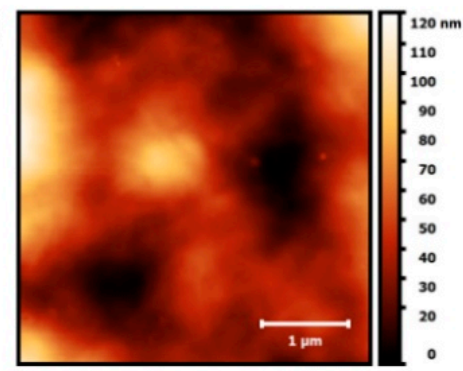

Figure 4. AFM images for films assembled under the conditions of pH 3.0 and (a) 3.5 bilayers, (b) 10.5 bilayers, and (c) 20.5 bilayers, respectively; and of pH 5.0 and (d) 3.5 bilayers, (e) 10.5 bilayers, and (f) 20.5 bilayers, respectively.

AFM results revealed that the increase in $\mathrm{pH}$ promoted the formation of more regular films with smoother surfaces. This result corroborates with the discussion on the conformation of the hyaluronic acid molecules within the studied $\mathrm{pH}$ range. The adsorption of a more coiled-shaped HA at pH 3.0 results in a rougher surface for films assembled in this pH condition.

On the other hand, the stiff conformation of both HA and CHI at pH 5.0 leads to a smoother surface on films built in this condition. It is also important to emphasize that the outermost layer of the films is composed of HA, which reinforces the role of charge density and assumed conformation of this polyelectrolyte not only in the film topography, but also in all surface properties. The increase in the number of bilayers, in turn, reveals a kind of roughness saturation in the coatings, which have a growth profile based on the construction of polymeric islands [70], which was also described in previous literature reports $[48,71]$.

\subsubsection{Capacitance}

Through atomic force microscopy analysis, the films were also characterized as to their capacitance. Figure 5 shows the obtained AFM images, while Table 2 contains the capacitance measurement values for some of the coatings produced in this project.

Table 2. Capacitance measurements of the nanometric coatings for different $\mathrm{pH}$ conditions and number of bilayers.

\begin{tabular}{ccc}
\hline $\mathbf{p H}$ Condition & Number of Bilayers & Capacitance $(\mathbf{m V})$ \\
\hline \multirow{3}{*}{3.00} & 3.5 & $119 \pm 23$ \\
& 10.5 & $122 \pm 29$ \\
\multirow{2}{*}{5.00} & 20.5 & $150 \pm 10$ \\
& 3.5 & $155 \pm 52$ \\
& 10.5 & $152 \pm 47$ \\
\hline
\end{tabular}


(a)

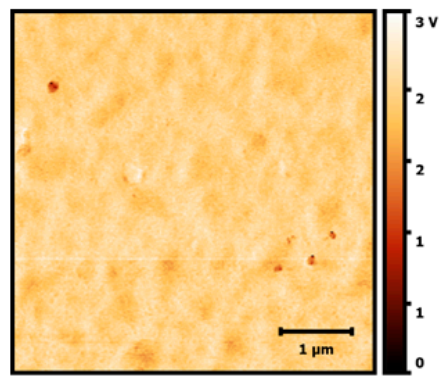

(d)

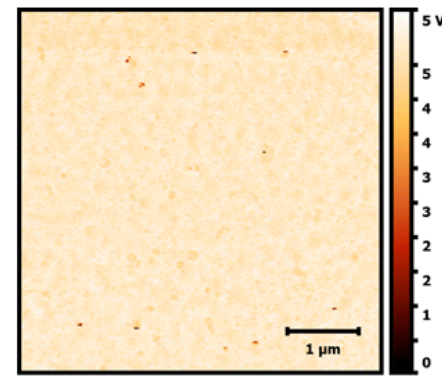

(b)

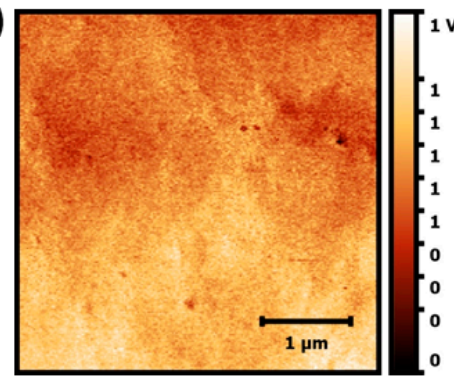

(e)

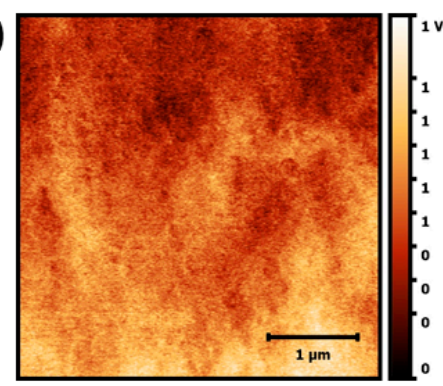

(c)

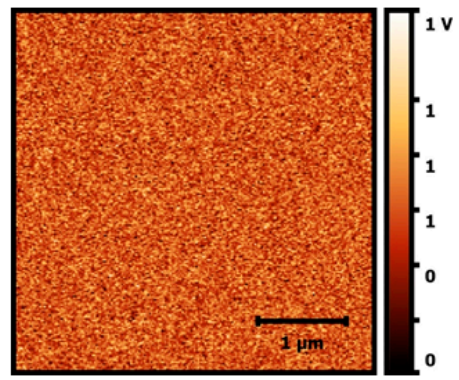

(f)

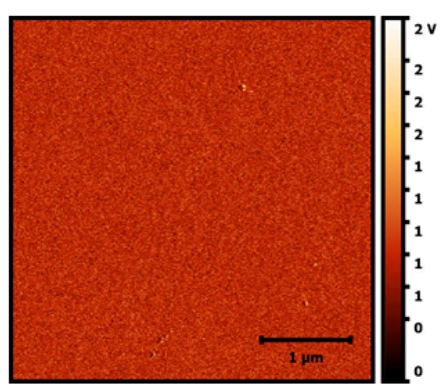

Figure 5. Distribution of loads in coatings prepared under the conditions of $\mathrm{pH} 3.0$ and (a) 3.5 bilayers, (b) 10.5 bilayers, and (c) 20.5 bilayers, respectively; and of pH 5.0 and (d) 3.5 bilayers, (e) 10.5 bilayers, and (f) 20.5 bilayers, respectively.

The capacitance results indicate that the films are electrically similar, though the films prepared at $\mathrm{pH} 5.0$ showed higher average capacitance and larger variability between trials.. Again, this result is a consequence of the greater electrostatic character assumed by the polyelectrolytes in this $\mathrm{pH}$ range. Moreover, previous work by our group has shown an association between smoother surfaces and higher charge mobility, which is in accordance with the results presented in this paper [4].

The surface charge of a substrate is known to have a significant influence on the cell adhesion process of several strains [56]. However, this property of $\mathrm{HA} / \mathrm{CHI}$ coatings still has an exploratory character, with the aim to investigate the correlation between charge mobility on the surface and the selectivity of films in the adhesion of circulating tumor cells. Nevertheless, recent studies on $\mathrm{HA} / \mathrm{CHI}$ films have pointed out to an inversely proportional relation between charge mobility and the average number of PC 3 cells adhered to the films [72].

\subsection{Cell Adhesion Assays}

Selective Potential of the Multilayer Films

The images of the tumor cells adhered to the films are shown in Figure 6 for different $\mathrm{pH}$ conditions and number of bilayers. For the 3.5 bilayers films, it was possible to verify the cellular adhesion in a clear way, with visually similar numbers of adhered cells in both $\mathrm{pH}$ conditions. These results corroborate the findings of previous works by Rocha Neto et al. (2020), which revealed an increase in the number of captured PC3 cells on $\mathrm{HA} / \mathrm{CHI}$ films with a decrease in $\mathrm{pH}$ levels, suggesting $\mathrm{pH}$ as a key factor for modulating cell adhesion [72]. As for the films with a higher number of bilayers, swelling of the films was observed in several regions, which made quantitative analyses of cell adhesion impossible. This event is evident in Figure $6 \mathrm{~d}$, where the upper part of the film reveals a very different structure to the lower part. 
(a)

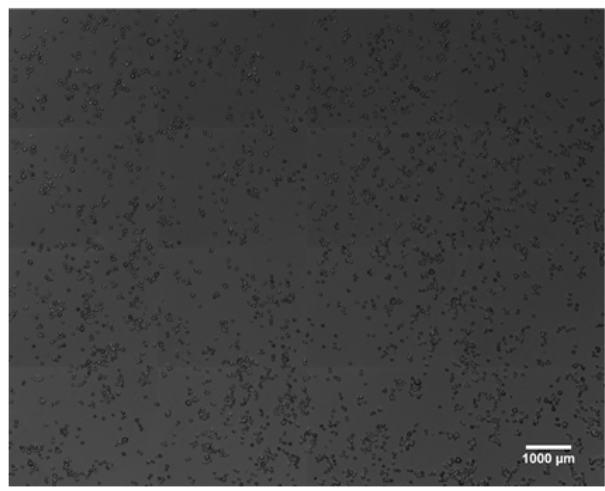

(c)

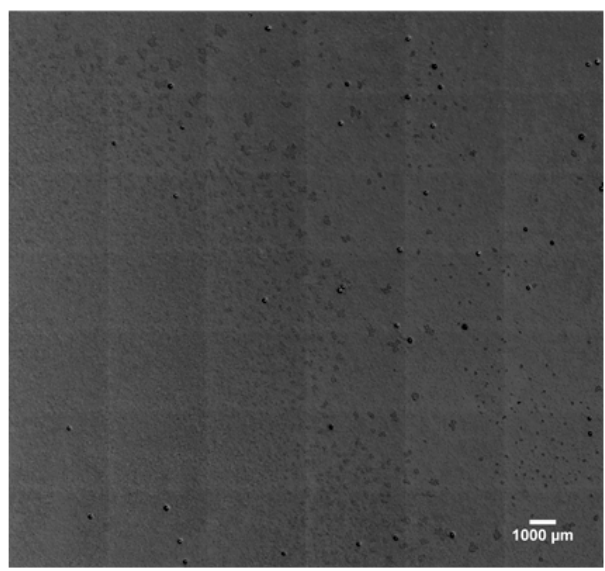

(b)

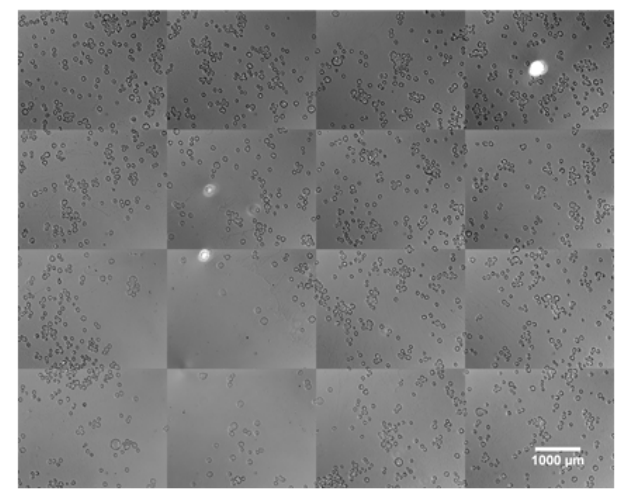

(d)

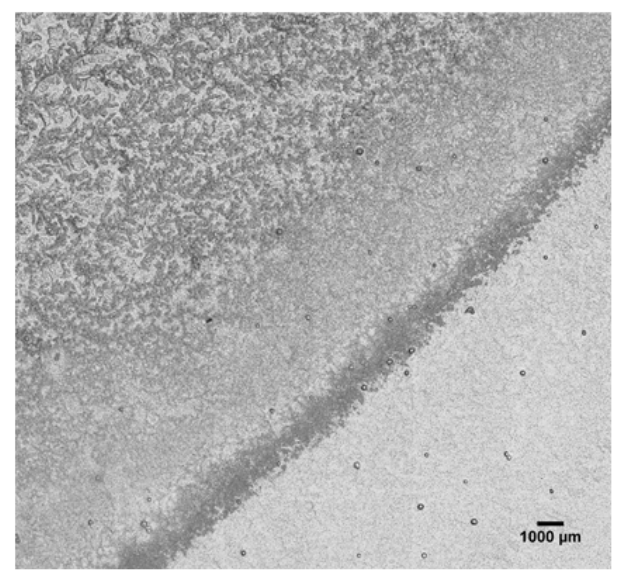

Figure 6. Microscope images of cell adhesion in the conditions of (a) $\mathrm{pH} 3.0$ and 3.5 bilayers, (b) $\mathrm{pH}$ 5.0 and 3.5 bilayers, (c) $\mathrm{pH} 3.0$ and 10.5 bilayers, and (d) $\mathrm{pH} 3.0$ and 20.5 bilayers.

By adjusting experimental variables such as $\mathrm{pH}$ of the polyelectrolytic solutions and number of bilayers, it was possible to promote changes in the physical and chemical properties of $\mathrm{HA} / \mathrm{CHI}$ multilayer films, changing the topographic profile, capacitance, thickness, availability of free functional groups, and hydrophilicity. For 3.5 bilayers, the films showed similar thicknesses across the entire $\mathrm{pH}$ range. Thus, according to the adhesion images obtained, it is suggested that thinner films have a high selective potential for prostate tumor cells.

However, it was not possible to verify the relationship between thicker films and the number of cells adhered due to the swelling of films prepared with more than 10.5 bilayers. One of the hypotheses raised for this issue is the dragging of the film during rinsing steps to remove the nonadherent cells.

Another possibility that can be considered is a change on film structure due to $\mathrm{pH}$ variations. The films were assembled at specific $\mathrm{pH}$ conditions, where the ionization of the polyelectrolytes is known. However, the cell adhesion assays are performed in a culture medium at $\mathrm{pH}$ 7.4. Thus, it is suggested that the change in $\mathrm{pH}$ condition during $1 \mathrm{~h}$ could have altered the electrostatic forces that maintain the cohesion between layers for thicker films. Kumorek et al. described the effects of medium $\mathrm{pH}$ on the disassembly of tannic acid (TA) and chitosan films. It was suggested that under significantly different $\mathrm{pH}$ conditions than those of film assembly, a change in the ionization profile of $\mathrm{CHI}$ and TA occurs, which compromises the electrostatic interaction between the molecules and, thus, leads to the disintegration of the multilayer films [73]. Moreover, recent investigations carried out by our group on the use of chitosan molecules with different degrees of deacetylation pointed to the control of $\mathrm{CHI}$ properties as a promising strategy to promote a higher stability of $\mathrm{HA} / \mathrm{CHI}$ films under $\mathrm{pH}$ levels close to physiological conditions [48]. Considering that, in this study, films developed under the same $\mathrm{pH}$ conditions were exposed in the same manner to the cell culture medium at physiological $\mathrm{pH}$, we also suggest that the 
disintegration of the films can be aggravated by an increase in the number of bilayers, therefore corroborating with the results observed for films of 10.5 and 20.5 bilayers in cell adhesion assays.

The increase in the $\mathrm{pH}$ of the polyelectrolytic solutions promoted the formation of films with smoother surfaces. As for the number of bilayers, roughness saturation was observed from 10.5 bilayers on. However, the roughness values have an order of magnitude of nanometers, while the cell size is in the order of micrometers. Thus, it is proposed that the tumor cells are not sensitive to the differences in roughness expressed by the films.

The capacitance of the coatings varied from $0.090 \mathrm{~V}$ to $0.163 \mathrm{~V}$. The assembly conditions explored did not promote large electrical differences between the films, disfavoring any comprehension of this property on the cell adhesion mechanism.

Regarding the hydrophilicity of nanometric films, it was found that the $\mathrm{pH} 3.0$ condition led to more hydrophilic films. However, the contact angle tests were performed over $10 \mathrm{~s}$, where the spread of water droplets on the surfaces of the coverings was monitored. In this period, very similar values were observed in the angles obtained for the 3.5-layer films in the studied $\mathrm{pH}$ range. In contrast, the cell adhesion tests lasted for $1 \mathrm{~h}$, which is assumed to be enough time for the culture medium to spread the same way in both 3.5-layer films, regardless of the $\mathrm{pH}$ condition.

\section{Conclusions}

The HA/CHI coatings developed via LbL exhibited significant selective potential in capturing the prostatic tumor line PC3, exploring the CD44-HA interaction. In addition to the presence of HA to promote cell adhesion into the films, we suggest that film thickness plays an important role in this mechanism. Thicker films tend to be unstable for applications that require contact with physiological environments. Therefore, our findings suggest that thinner films are more suitable to induce tumor cell capture. Moreover, it was found that HA/CHI films with 3.5 bilayers at $\mathrm{pH} 3.0$ provided the optimum condition for cell adhesion in this study.

Since cell adhesion on substrates is a surface phenomenon, this study suggests that the topography and availability of functional groups act as key factors for the development of biomaterials suitable for this application. By understanding the PC3 lineage as a tumor cell model, there is a potential application of $\mathrm{HA} / \mathrm{CHI}$ coatings as platforms for the selective capture of tumor lineages, as the CD44-HA interaction is susceptible to applications in rapid diagnostic devices, cascades of cell signaling, and biosensor mechanisms.

Author Contributions: Conceptualization, G.G.L., J.B.M.R.N., and M.M.B.; methodology, G.G.L. and J.B.M.R.N.; software, J.B.M.R.N.; validation, G.G.L., H.F.d.C., and J.B.M.R.N.; formal analysis, G.G.L. and J.B.M.R.N.; investigation, G.G.L. and J.B.M.R.N.; resources, H.F.d.C. and M.M.B.; data curation, G.G.L. and J.B.M.R.N.; writing—original draft preparation, G.G.L. and J.B.M.R.N.; writing—review and editing, all authors; visualization, all authors; supervision, M.M.B. and H.F.d.C.; project administration, M.M.B.; funding acquisition, M.M.B. All authors have read and agreed to the published version of the manuscript.

Funding: This research was funded by São Paulo Research Foundation (FAPESP, grant No. 2018/ 20560-4) and National Council for Scientific and Technological Development (CNPq, grant No.147536/ 2016-2).

Institutional Review Board Statement: Not applicable.

Informed Consent Statement: Not applicable.

Acknowledgments: We thank Analytical Resources and Calibration Laboratory (LRAC) from School of Chemical Engineering (Unicamp) and the Brazilian Nanotechnology National Laboratory (LNNano, CNPEM) for the analytical facilities. We acknowledge CNPq (grant n.147536/2016-2) and São Paulo Research Foundation (FAPESP, grant n. 2018/20560-4) for the financial support to conduct this project.

Conflicts of Interest: The authors declare no conflict of interest. 


\section{References}

1. Dahm, P.; Neuberger, M.; Ilic, D. Screening for prostate cancer: Shaping the debate on benefits and harms. Cochrane Database Syst. Rev. 2013, ED000067. [CrossRef]

2. Rodrigues, V.C.; Soares, J.C.; Soares, A.C.; Braz, D.C.; Melendez, M.E.; Ribas, L.C.; Scabini, L.F.S.; Bruno, O.M.; Carvalho, A.L.; Reis, R.M.; et al. Electrochemical and optical detection and machine learning applied to images of genosensors for diagnosis of prostate cancer with the biomarker PCA3. Talanta 2021, 222, 121444. [CrossRef] [PubMed]

3. Bertoldo, S.A.; PASQUINI, V.Z. Câncer de próstata: Um desafio para saúde do homem. Revi Enfer UNISA 2010, 11, 138-142.

4. Neto, J.B.M.R.; Taketa, T.B.; Bataglioli, R.A.; Pimentel, S.B.; Santos, D.M.; Fiamingo, A.; Costa, C.A.R.; Campana-Filho, S.P.; Carvalho, H.F.; Beppu, M.M. Tailored chitosan/hyaluronan coatings for tumor cell adhesion: Effects of topography, charge density and surface composition. Appl. Surf. Sci. 2019, 486, 508-518. [CrossRef]

5. Neto, J.B.M.R.; Soares, A.C.; Bataglioli, R.A.; Carr, O.; Costa, C.A.R.; Oliveira, O.N.; Beppu, M.M.; Carvalho, H.F. Polysaccharide Multilayer Films in Sensors for Detecting Prostate Tumor Cells Based on Hyaluronan-CD44 Interactions. Cells 2020, 9, 1563. [CrossRef] [PubMed]

6. Swiston, A.J.; Cheng, C.; Um, S.H.; Irvine, D.J.; Cohen, R.E.; Rubner, M.F. Surface functionalization of living cells with multilayer patches. Nano Lett. 2008, 8, 4446-4453. [CrossRef]

7. Vasconcellos, F.C.; Swiston, A.J.; Beppu, M.M.; Cohen, R.E.; Rubner, M.F. Bioactive Polyelectrolyte Multilayers: Hyaluronic Acid Mediated B Lymphocyte Adhesion. Biomacromolecules 2010, 11, 2407-2414. [CrossRef]

8. Zöller, M. CD44: Can a cancer-initiating cell profit from an abundantly expressed molecule? Nat. Rev. Cancer 2011, 11, 254-267. [CrossRef]

9. Chen, C.; Zhao, S.; Karnad, A.; Freeman, J.W. The biology and role of CD44 in cancer progression: Therapeutic implications. J. Hematol. Oncol. 2018, 11, 1-23. [CrossRef]

10. Stern, R. Hyaluronan in Cancer Biology; Academic Press: San Diego, CA, USA, 2009.

11. Sneath, R.J.; Mangham, D.C. The normal structure and function of CD44 and its role in neoplasia. Mol. Pathol. 1998, 51, 191-200. [CrossRef]

12. Li, W.; Ma, H.; Zhang, J.; Zhu, L.; Wang, C.; Yang, Y. Unraveling the roles of CD44/CD24 and ALDH1 as cancer stem cell markers in tumorigenesis and metastasis. Sci. Rep. 2017, 7, 13856. [CrossRef]

13. Assis, O.B.G. Caracterização estrutural e da capacidade de absorção de água em filmes finos de quitosana processados em diversas concentrações. Polímeros 2003, 13, 223-228. [CrossRef]

14. De Moura, C.M.; de Moura, J.M.; Soares, N.M.; de Almeida Pinto, L.A. Evaluation of molar weight and deacetylation degree of chitosan during chitin deacetylation reaction: Used to produce biofilm, Chem. Eng. Process. Chem. Eng. Process. Process Intensif. 2011, 50, 351-355. [CrossRef]

15. Rinaudo, M. Chitin and chitosan: Properties and applications. Prog. Polym. Sci. 2006, 31, 603-632. [CrossRef]

16. Ahmed, S.; Ikram, S. Chitosan: Derivatives, Composites and Applications; John Wiley \& Sons: Hoboken, NJ, USA, 2017; 516p.

17. Peniche, C.; Argüelles-Monal, W.; Goycoolea, F.M. Chitin and Chitosan: Major Sources, Properties and Applications. In Monomers, Polymers and Composites from Renewable Resources; Elsevier: Kidlington, UK, 2008; pp. 517-542. [CrossRef]

18. Zamani, A.; Edebo, L.; Sjöström, B.; Taherzadeh, M.J. Extraction and Precipitation of Chitosan from Cell Wall of Zygomycetes Fungi by Dilute Sulfuric Acid. Biomacromolecules 2007, 8, 3786-3790. [CrossRef] [PubMed]

19. Younes, I.; Rinaudo, M. Chitin and Chitosan Preparation from Marine Sources. Structure, Properties and Applications. Mar. Drugs 2015, 13, 1133-1174. [CrossRef] [PubMed]

20. Delezuk, J.A.d.M.; Cardoso, M.B.; Domard, A.; Campana-Filho, S.P. Ultrasound-assisted deacetylation of beta-chitin: Influence of processing parameters. Polym. Int. 2011, 60, 903-909. [CrossRef]

21. Verlee, A.; Mincke, S.; Stevens, C.V. Recent developments in antibacterial and antifungal chitosan and its derivatives. Carbohydr. Polym. 2017, 164, 268-283. [CrossRef] [PubMed]

22. Park, S.-C.; Nah, J.-W.; Park, Y. pH-dependent mode of antibacterial actions of low molecular weight water-soluble chitosan (LMWSC) against various pathogens. Macromol. Res. 2011, 19, 853-860. [CrossRef]

23. Krajewska, B.; Wydro, P.; Jańczyk, A. Probing the Modes of Antibacterial Activity of Chitosan. Effects of pH and Molecular Weight on Chitosan Interactions with Membrane Lipids in Langmuir Films. Biomacromolecules 2011, 12, 4144-4152. [CrossRef]

24. Costa, E.M.; Silva, S.; Pina, C.; Tavaria, F.K.; Pintado, M.M. Evaluation and insights into chitosan antimicrobial activity against anaerobic oral pathogens. Anaerobe 2012, 18, 305-309. [CrossRef]

25. Sutar, Y.B.; Telvekar, V.N. Chitosan based copolymer-drug conjugate and its protein targeted polyelectrolyte complex nanoparticles to enhance the efficiency and specificity of low potency anticancer agent. Mater. Sci. Eng. C 2018, 92, 393-406. [CrossRef]

26. Ahsan, S.M.; Thomas, M.; Reddy, K.K.; Sooraparaju, S.G.; Asthana, A.; Bhatnagar, I. Chitosan as biomaterial in drug delivery and tissue engineering. Int. J. Biol. Macromol. 2018, 110, 97-109. [CrossRef] [PubMed]

27. Suresh, L.; Brahman, P.K.; Reddy, K.R.; Bondili, J.S. Development of an electrochemical immunosensor based on gold nanoparticles incorporated chitosan biopolymer nanocomposite film for the detection of prostate cancer using PSA as biomarker. Enzym. Microb. Technol 2018, 112, 43-51. [CrossRef]

28. Rodrigues, V.C.; Moraes, M.L.; Soares, J.C.; Soares, A.C.; Sanfelice, R.; Deffune, E.; Oliveira, O.N., Jr. Immunosensors made with layer-by-layer films on chitosan/gold nanoparticle matrices to detect D-dimer as biomarker for venous thromboembolism. Bull. Chem. Soc. Jpn. 2018, 91, 891-896. [CrossRef] 
29. Tamer, T.M.; Valachová, K.; Hassan, M.A.; Omer, A.M.; El-Shafeey, M.; Eldin, M.S.M.; Šoltés, L. Chitosan/hyaluronan/edaravone membranes for anti-inflammatory wound dressing: In vitro and in vivo evaluation studies. Mater. Sci. Eng. C 2018, 90, 227-235. [CrossRef]

30. Soundarya, S.P.; Menon, A.H.; Chandran, S.V.; Selvamurugan, N. Bone tissue engineering: Scaffold preparation using chitosan and other biomaterials with different design and fabrication techniques. Int. J. Biol. Macromol. 2018, 119, 1228-1239. [CrossRef] [PubMed]

31. Nezhad-Mokhtari, P.; Akrami-Hasan-Kohal, M.; Ghorbani, M. An injectable chitosan-based hydrogel scaffold containing gold nanoparticles for tissue engineering applications. Int. J. Biol. Macromol. 2020, 154, 198-205. [CrossRef]

32. Coma, V.; Deschamps, A.; Martial-Gros, A. Bioactive Packaging Materials from Edible Chitosan Polymer-Antimicrobial Activity Assessment on Dairy-Related Contaminants. J. Food Sci. 2003, 68, 2788-2792. [CrossRef]

33. Zivanovic, S.; Chi, S.; Draughon, A.F. Antimicrobial Activity of Chitosan Films Enriched with Essential Oils. J. Food Sci. 2005, 70, 45-51. [CrossRef]

34. Arkoun, M.; Ardila, N.; Heuzey, M.-C.; Ajji, A. Chitosan-Based Structures/Coatings With Antibacterial Properties. Handb. Antimicrob. Coat. 2018, 357-389. [CrossRef]

35. Belbekhouche, S.; Bousserrhine, N.; Alphonse, V.; Carbonnier, B. From beta-cyclodextrin polyelectrolyte to layer-by-layer self-assembly microcapsules: From inhibition of bacterial growth to bactericidal effect. Food Hydrocoll. 2019, 95, 219-227. [CrossRef]

36. Kogan, G.; Šoltés, L.; Stern, R.; Gemeiner, P. Hyaluronic acid: A natural biopolymer with a broad range of biomedical and industrial applications. Biotechnol. Lett. 2007, 29, 17-25. [CrossRef] [PubMed]

37. Rinaudo, M. Main properties and current applications of some polysaccharides as biomaterials. Polym. Int. 2008, 57, 397-430. [CrossRef]

38. Fallacara, A.; Baldini, E.; Manfredini, S.; Vertuani, S. Hyaluronic acid in the third millennium. Polymers 2018, 10, 701. [CrossRef]

39. Bowman, S.; Awad, M.E.; Hamrick, M.W.; Hunter, M.; Fulzele, S. Recent advances in hyaluronic acid based therapy for osteoarthritis. Clin. Transl. Med. 2018, 7, 6. [CrossRef]

40. Liu, X.-W.; Hu, J.; Man, C.; Zhang, B.; Ma, Y.-Q.; Zhu, S.-S. Insulin-like growth factor-1 suspended in hyaluronan improves cartilage and subchondral cancellous bone repair in osteoarthritis of temporomandibular joint. Int. J. Oral Maxillofac. Surg. 2011, 40, 184-190. [CrossRef]

41. Bartlett, S.; Lin, K.; Bartlett, S.; Matsuo, K.; Livolsi, V.; Parry, C.; Hass, B.; Whitaker, L. Hyaluronic acid-filled mammary implants: An experimental study. Plast. Reconstr. Surg. 1994, 94, 306-315.

42. Patterson, J.; Siew, R.; Herring, S.W.; Lin, A.S.P.; Guldberg, R.; Stayton, P.S. Hyaluronic acid hydrogels with controlled degradation properties for oriented bone regeneration. Biomaterials 2010, 31, 6772-6781. [CrossRef]

43. Prestwich, G.D. Hyaluronic acid-based clinical biomaterials derived for cell and molecule delivery in regenerative medicine. J. Control. Release 2011, 155, 193-199. [CrossRef]

44. Lu, B.; Luo, D.; Zhao, A.; Wang, H.; Zhao, Y.; Maitz, M.F.; Yang, P.; Huang, N. pH responsive chitosan and hyaluronic acid layer by layer film for drug delivery applications. Prog. Org. Coat. 2019, 135, 240-247. [CrossRef]

45. Taketa, T.B.; Bataglioli, R.A.; Neto, J.B.M.R.; Beppu, M.M. Probing axial metal distribution on biopolymer-based layer-by-layer films for antimicrobial use. Colloids Surf. B Biointerfaces 2021, 199, 111505. [CrossRef] [PubMed]

46. Hernández-Montelongo, J.; Nascimento, V.F.; Murillo, D.; Taketa, T.B.; Sahoo, P.; de Souza, A.A.; Beppu, M.M.; Cotta, M.A. Nanofilms of hyaluronan/chitosan assembled layer-by-layer: An antibacterial surface for Xylella fastidiosa. Carbohydr. Polym. 2016, 136, 1-11. [CrossRef]

47. Swiston, A.J.; Gilbert, J.B.; Irvine, D.J.; Cohen, R.E.; Rubner, M.F. Freely suspended cellular "backpacks" lead to cell aggregate self-assembly. Biomacromolecules 2010, 11, 1826-1832. [CrossRef] [PubMed]

48. Neto, J.B.M.R.; Lima, G.G.; Fiamingo, A.; Germiniani, L.G.L.; Taketa, T.B.; Bataglioli, R.A.; da Silveira, G.A.T.; da Silva, J.V.L.; Campana-Filho, S.P.; Oliveira, O.N., Jr. Controlling antimicrobial activity and drug loading capacity of chitosan-based layer-bylayer films. Int. J. Biol. Macromol. 2021, 172, 154-161. [CrossRef] [PubMed]

49. Xu, H.; Ma, L.; Shi, H.; Gao, C.; Han, C. Chitosan-hyaluronic acid hybrid film as a novel wound dressing: In vitro and in vivo studies. Polym. Adv. Technol. 2007, 18, 869-875. [CrossRef]

50. Lin, Q.-K.; Ren, K.-F.; Ji, J. Hyaluronic acid and chitosan-DNA complex multilayered thin film as surface-mediated nonviral gene delivery system. Colloids Surf. B Biointerfaces 2009, 74, 298-303. [CrossRef]

51. Soliman, O.Y.; Alameh, M.G.; de Cresenzo, G.; Buschmann, M.D.; Lavertu, M. Efficiency of Chitosan/Hyaluronan-Based mRNA Delivery Systems In Vitro: Influence of Composition and Structure. J. Pharm. Sci. 2020, 109, 1581-1593. [CrossRef] [PubMed]

52. Tang, Q.; Hu, Z.; Jin, H.; Zheng, G.; Yu, X.; Wu, G.; Liu, H.; Zhu, Z.; Xu, H.; Zhang, C.; et al. Microporous polysaccharide multilayer coated BCP composite scaffolds with immobilised calcitriol promote osteoporotic bone regeneration both in vitro and in vivo. Theranostics 2019, 9, 1125-1143. [CrossRef] [PubMed]

53. Decher, G. Fuzzy nanoassemblies: Toward layered polymeric multicomposites. Science 1997, 277, 1232-1237. [CrossRef]

54. Klitzing, R.V. Internal structure of polyelectrolyte multilayer assemblies. Phys. Chem. Chem. Phys. 2006, 8, 5012-5033. [CrossRef]

55. Ariga, K.; Hill, J.P.; Ji, Q. Layer-by-layer assembly as a versatile bottom-up nanofabrication technique for exploratory research and realistic application. Phys. Chem. Chem. Phys. 2007, 9, 2319-2340. [CrossRef] 
56. Guo, S.; Zhu, X.; Loh, X.J. Controlling cell adhesion using layer-by-layer approaches for biomedical applications. Mater. Sci. Eng. C 2017, 70, 1163-1175. [CrossRef] [PubMed]

57. Berg, M.C.; Yang, S.Y.; Hammond, P.T.; Rubner, M.F. Controlling Mammalian Cell Interactions on Patterned Polyelectrolyte Multilayer Surfaces. Langmuir 2004, 20, 1362-1368. [CrossRef]

58. Richert, L.; Lavalle, P.; Payan, E.; Shu, X.Z.; Prestwich, G.D.; Schaaf, P.; Voegel, J.; Picart, C. Layer by Layer Buildup of Polysaccharide Films: Physical Chemistry and Cellular Adhesion Aspects. Langmuir 2004, 20, 448-458. [CrossRef]

59. Dubas, S.T.; Schlenoff, J.B. Factors Controlling the Growth of Polyelectrolyte Multilayers. Macromolecules 1999, 32, 8153-8160. [CrossRef]

60. Shiratori, S.S.; Rubner, M.F. pH-Dependent Thickness Behavior of Sequentially Adsorbed Layers of Weak Polyelectrolytes. Macromolecules 2000, 33, 4213-4219. [CrossRef]

61. Yoo, D.; Shiratori, S.S.; Rubner, M.F. Controlling bilayer composition and surface wettability of sequentially adsorbed multilayers of weak polyelectrolytes. Macromolecules 1998, 31, 4309-4318. [CrossRef]

62. Li, D.; Dai, F.; Li, H.; Wang, C.; Shi, X.; Cheng, Y.; Deng, H. Chitosan and collagen layer-by-layer assembly modified oriented nanofibers and their biological properties. Carbohydr. Polym. 2021, 254, 117438. [CrossRef] [PubMed]

63. Manabe, K.; Belbekhouche, S. Construction of low-wettable free-standing layer-by-layer multilayer for fibrinogen adsorption. Colloids Surf. A Physicochem. Eng. Asp. 2020, 604, 125303. [CrossRef]

64. Ding, C.; Xu, S.; Wang, J.; Liu, Y.; Hu, X.; Chen, P.; Feng, S. Controlled loading and release of methylene blue from LbL polyurethane/poly(acrylic acid) film. Polym. Adv. Technol. 2012, 23, 1283-1286. [CrossRef]

65. Da Câmara, P.C.F.; Balaban, R.C.; Hedayati, M.; Popat, K.C.; Martins, A.F.; Kipper, M.J. Novel cationic tannin/glycosaminoglycanbased polyelectrolyte multilayers promote stem cells adhesion and proliferation. RSC Adv. 2019, 9, 25836-25846. [CrossRef]

66. Taketa, T.B. Obtenção e caracterização de recobrimentos de quitosana/ácido hialurônico e quitosana/alginato de sódio pela técnica layer-by-layer para aplicações antimicóticas. Master's Thesis, Universidade Estadual de Campinas, Campinas, Brazil, 2013.

67. Tsaih, M.L.; Chen, R.H. Effects of Ionic Strength and pH on the Diffusion Coefficients and Conformation of Chitosans Molecule in Solution. J. Appl. Polym. Sci. 1999, 73, 2041-2050. [CrossRef]

68. Nascimento, V.; Franca, C.; Hernández-Montelongo, J.; Machado, D.; Lancellotti, M.; Cotta, M.; Landers, R.; Beppu, M. Influence of $\mathrm{pH}$ and ionic strength on the antibacterial effect of hyaluronic acid/chitosan films assembled layer-by-layer. Eur. Polym. J. 2018, 109, 198-205. [CrossRef]

69. Ranella, A.; Barberoglou, M.; Bakogianni, S.; Fotakis, C.; Stratakis, E. Tuning cell adhesion by controlling the roughness and wettability of 3D micro/nano silicon structures. Acta Biomater. 2010, 6, 2711-2720. [CrossRef]

70. Zhang, S.; Liu, W.; Liang, J.; Li, X.; Liang, W.; He, S.; Zhu, C.; Mao, L. Buildup mechanism of carboxymethyl cellulose and chitosan self-assembled films. Cellulose 2013, 20, 1135-1143. [CrossRef]

71. Picart, C.; Mutterer, J.; Richert, L.; Luo, Y.; Prestwich, G.D.; Schaaf, P.; Voegel, J.-C.; Lavalle, P. Molecular basis for the explanation of the exponential growth of polyelectrolyte multilayers. Proc. Natl. Acad. Sci. USA 2002, 99, 12531-12535. [CrossRef]

72. Neto, J.B.M.R.; Neto, R.J.G.; Bataglioli, R.A.; Taketa, T.B.; Pimentel, S.B.; Baratti, M.O.; Costa, C.A.R.; Carvalho, H.F.; Beppu, M.M. Engineering the surface of prostate tumor cells and hyaluronan/chitosan multilayer films to modulate cell-substrate adhesion properties. Int. J. Biol. Macromol. 2020, 158, 197-207. [CrossRef]

73. Kumorek, M.; Minisy, I.M.; Krunclová, T.; Voršiláková, M.; Venclíková, K.; Chánová, E.M.; Janoušková, O.; Kubies, D. pHresponsive and antibacterial properties of self-assembled multilayer films based on chitosan and tannic acid. Mater. Sci. Eng. C 2020, 109, 110493. [CrossRef] 